Jurnal Ilmu dan Teknologi Kesehatan

Vol 8, No 1, September 2020,

ISSN: 2338-9095 (Print)

ISSN: 2338-9109 (online)

\title{
Supportive Educative Nursing Program Effectively Increasing Self Care for Heart Failure Patients
}

\author{
Ida Ayu Agung Laksmi ${ }^{1}$, Putu Wira Kusuma Putra ${ }^{2}$, I Kadek Sudika ${ }^{3}$ \\ ${ }^{1,2}$ STIKES Bina Usada Bali, Indonesia \\ ${ }^{3}$ RSD Mangusada, Indonesia \\ Email: agunglaksmi41@gmail.com
}

\begin{abstract}
Article history
Posted, Aug 5th, 2020

Reviewed, Sept 10th, 2020

Received, Sept 27th, 2020
\end{abstract}

\begin{abstract}
Heart failure patients generally experience activity intolerance resulting in functional limitations and decreased self-care abilities. One of the systems identified Orem in patients with self-care fulfillment barriers is the supportive educational system, which is an effort to assist patients who need educational support in the hope that patients will need independent care. This study aimed to determine the effect of the supportive educative nursing program on self-care for heart failure patients. This research method was a quasi-experimental research with a pre-post-test control group design approach. A sample of 28 respondents was divided into treatment groups that received a supportive educative nursing program and a control group given education according to discharge planning procedures at Mangusada Regional Hospital. The questionnaire used was the Self Care Heart Failure Index (SCHFI). Data were analyzed using an independent T-test. The result of this study showed that there were significant differences between self-care in the intervention and control group with a p-value (0.017), where $p<\alpha(0.05)$, which means that statistically providing supportive educative nursing program was more effective compared to ordinary education. Providing supportive educative nursing programs can be used as nursing interventions to improve patients' independent care with heart failure.
\end{abstract}

Keywords: heart failure; self-care; supportive educative nursing program

\begin{abstract}
ABSTRAK
Pasien gagal jantung umumnya mengalami intoleransi aktifitas sehingga terjadi keterbatasan fungsional dan penurunan kemampuan self care. Salah satu sistem yang diidentifikasi Orem pada pasien dengan hambatan pemenuhan self care adalah supportive-educative system, yaitu suatu upaya memberikan bantuan pada pasien yang membutuhkan dukungan pendidikan dengan harapan pasien mampu memerlukan perawatan secara mandiri. Tujuan penelitian ini untuk mengetahui pengaruh Program Edukatif Suportif (Produktif) terhadap Self Care pasien gagal jantung. Metode penelitian ini adalah penelitian quasy-experimental dengan pendekatan
\end{abstract}


pre test-post test with control grup design. Sampel sebanyak 28 orang dibagi menjadi kelompok perlakuan yang mendapatkan program suportif edukatif dan kelompok kontrol yang diberikan edukasi sesuai prosedur discharge planning di RSUD Mangusada. Kuesioner yang digunakan adalah Self Care Heart Failure Index (SCHFI). Data dianalisis dengan menggunakan uji Independent $\mathrm{T}$ test. Hasil penelitian menunjukkan bahwa terdapat perbedaan yang signifikan antara self care pada kelompok intervensi dengan self care pada kelompok kontrol dengan nilai p 0.017 yang berarti bahwa secara statistik pemberian program edukatif-supportif (produktif) lebih efektif dibandingkan dengan edukasi biasa. Program edukatif-supportif (produktif) dapat digunakan sebagai intervensi keperawatan dalam meningkatkan kemampuan merawat diri pada pasien gagal jantung.

Kata Kunci: gagal jantung; self care; program keperawatan edukatif-supportif

\section{INTRODUCTION}

Heart failure is a progressive health problem with high mortality and morbidity rates in developed and developing countries. An estimated 5 million people in the United States have heart failure, predominantly elderly, with nearly $80 \%$ of cases occurring in patients over the age of 65 with a mortality rate of around 45-50\% (O'Connor et al., 2009). In Indonesia, heart failure patients are relatively younger than Europe and America, accompanied by a more severe clinical appearance (PERKI, 2015). According to the Ministry of Health's basic health research (2013), heart failure prevalence based on interviews with diagnosed doctors in Indonesia is $0.13 \%$ or an estimated 229,696 people (Kemenkes, 2013).

In general, heart failure is caused by myocardial problems (coronary heart disease, cardiomyopathy, myocarditis), and mechanical disorders of the myocardium (hypertension, aortic stenosis, aortic coarctation) (Kabo, 2012). Impaired ventricular ability to store or eject blood causes breathlessness and fatigue, limiting activity tolerance (Pereira et al., 2016). Generally, patients with heart failure will experience activity intolerance resulting in functional limitations. Functional limitations will affect the ability of heart failure patients to perform self-care.

According to Dorothea Orem, self-care is an action in optimizing a person's ability to care for himself independently so that the ability to maintain his health and well-being is achieved (Alligood, 2014). A person can take care of himself, which is called a selfcare agency. Self-care agency for heart disease sufferers has decreased due to prolonged illness (Indiarti, 2014). Britz and Dunn (2010) found that most heart failure patients had not carried out proper self-care as taught, such as a low salt diet, regular physical activity, fluid restriction, and daily 
weight monitoring. The inability to carry out self-care can be a factor affecting the rehospitalization of heart failure patients. One of the systems identified by Orem for patients with barriers to fulfilling self-care is a supportive-educative system, which is an effort to assist patients who need educational support in the hope that patients will be able to require independent care. This system is carried out to perform nursing actions after learning (Alligood, 2014). According to Etemadifar et al. (2014), the supportive-educative system is an effective intervention given by nurses to families and heart failure patients. This intervention is simple, inexpensive, and practical to provide. Heart failure patients will perform self-care if there is an understanding of different aspects of therapeutic self-care behavior so that the most appropriate intervention is to provide appropriate supportive-educative care (Zamanzadeh et al., 2013).

Data on heart failure patients at the Mangusada Regional Hospital shows that the number of people with heart failure has increased. The number of patients visiting the cardiac polyclinic in 2015 was 98, increasing to 872 in 2017 (Mangusada Regional Hospital, 2018). This high number of visits was also due to the rehospitalization of old patients. Lakdizaji et al., (2013) provide a similar intervention, namely the provision of educational programs by the Heart Failure Society of America (HFSA) Module. It includes education related to heart failure control, low-salt regimens, drugs, self-care, physical activity, feelings, tips for either family or patients. The results of this study indicate that the educational program provided has a significant impact on improving the quality of life for heart failure patients. Another study by Zamanzadeh et al., (2013) also provides educational assistance programs based on the 2010 Heart Failure Society of America (HFSA) executive guide booklet. The results have a significant impact on increasing the self-care ability of heart failure respondents in Iran.

Based on these two studies, this study is the first study in Bali Province, which aims to develop a holistic nursing intervention in heart failure patients through supportive educational programs so that self-care for heart failure patients increases and the quality of life also increases. Therefore, this study aimed to provide supportiveeducational management of self-care fulfillment for patients with heart failure.

\section{METHOD}

A quasi-experimental study with a control group design was conducted in Mangusada 
Regional Hospital, Bali, from June 2020 to July 2020. The population in this study is all heart failure patients who were treated at the Mangusada Regional Hospital. Based on the preliminary study, it was found that the average inpatient with heart failure cases in the ICU room at Mangusada Hospital for the last three months was 30 people. The sample was calculated using a population formula of less than 1,000 (Sugiyono, 2011) and obtained a sample of 28 heart failure patients divided into the intervention group and the control group. The respondents' selection based on purposive sampling technique with inclusion criteria were heart failure patients who had a minimal level of dependence, were able to read and write, and were willing to become respondents. In contrast, the exclusion criteria were heart failure patients with neurological disorders (cognitive dysfunction), stroke, and kidney failure.

The self-care ability was measured using the Self Care Heart Failure Index (SCHFI) questionnaire modified by Kaawoan (2012), which is consists of 20 questions divided into section A (8 question items that identify self-care maintenance) section B (6 question items that identify self-care management) and section $\mathrm{C}$ (6 questions that identify selfcare confidence). The results of the modified SCHFI questionnaire validity test did not have a question item with a value of $r<3$ The reliability test showed the value of Cronbach alpha $=0.956$, so it is valid and reliable (Kaawoan, 2012). In the intervention group, respondents were given a supportive-educational program, a structured educational program with nurse assistance by telephone and home visits equipped with booklets and self-care management videos for heart failure. In contrast, in the control group, education was given according to discharge planning procedures applicable to the hospital. After eight weeks, the respondents returned to fill out the SCHFI questionnaire as post-test data.

This study has received ethical approval by the Health Research Ethics Commission of STIKES Bina Usada Bali with number 079 /EA /KEPK-BUB-2020 and from the Mangusada Regional Hospital the number 800/5514 / RSDM / VI / 2020. 


\section{RESULTS AND DISCUSSION}

Table 1. Descriptive of Self Care Respondent Heart Failure

\begin{tabular}{lll}
\hline Group & N & Mean \pm SD \\
\hline Pre-Test Control Group & 14 & $46.29 \pm 6.888$ \\
\hline Post-Test Control Group & 14 & $48.00 \pm 6.816$ \\
\hline Pre-Test Intervention Group & 14 & $45.86 \pm 6.655$ \\
\hline Post-Test Intervention Group & 14 & $68.07 \pm 2.841$ \\
\hline
\end{tabular}

Table 1 shows that the self-care pre-test using the SCHFI questionnaire in the intervention group was 45.86 , and in the control group 46.29. These results indicate that the average self-care in both groups is in the unfavorable category. This study's results are in line with Britz and Dunn (2010), who found that some heart failure patients reported that they had not implemented self-care appropriately as taught. Wahyuni and Kurnia (2014) found that $56.2 \%$ of heart failure patients had selfcare, which is not good. Heart failure experienced by patients affects the individual as a whole, including personality, adaptability, and hope for a healthy life. In patients with heart failure, volume or pressure overload or regional dysfunction heart occurs, which will increase the workload of the heart, causing signs and symptoms such as shortness of breath and fatigue during activity (PERKI, 2015). Generally, patients with heart failure will experience activity intolerance resulting in functional limitations. Functional limitations will affect the ability of heart failure patients to perform self-care.

The mean self-care in heart failure patients after eight weeks of being given a supportive educative nursing program in the intervention group increased to 68.07 , and the mean of self-care in the control group increased to 48.00 . It means that there is an increase in self-care in both groups. According to Ibrahim, Tawfik, and Abudari (2016), self-care management is a control measure that aims to maintain a balance between health status and symptoms of heart failure, where the process starts from symptom recognition, symptom evaluation, treatment implementation to evaluation. In both the control and intervention groups, respondents are given education about heart failure self-care. In this study, self-care indicators that experience changes after being given effective and educational programs, especially in self-care maintenance and self-care management. Heart failure patients have started to routinely weigh body weight, have their legs checked for swelling, begin to understand 
routine activities or sports and, reduce salt

consumption.

Table 2. Data Normality Test Results with the Shapiro-Wilk Test (CI 95\%)

\begin{tabular}{lll}
\hline Group & N & p-value \\
\hline Pre-Test Control Group & 14 & 0.954 \\
\hline Post-Test Control Group & 14 & 0.786 \\
\hline Pre-Test Intervention Group & 14 & 0.993 \\
\hline Post-Test Intervention Group & 14 & 0.404 \\
\hline
\end{tabular}

Table 3. Paired T-Test Results in the Intervention Group (CI 95\%)

\begin{tabular}{|c|c|c|c|c|}
\hline & Mean \pm SD & $\Delta$ Mean \pm SD & $\mathbf{t}$ & p-value \\
\hline Pre-Test & $45.86 \pm 6.655$ & $-22.214 \pm 7.618$ & -10.9111 & $<0.001$ \\
\hline Post-Test & $68.07 \pm 2.841$ & & & \\
\hline
\end{tabular}

Based on table 3 , it can be seen that there is a significant difference between the respondent's self-care before and after being given a supportive educative nursing program with a p-value $<0.001$. This statistical value shows that a supportive educative nursing program can increase the respondent's self-care from an average of 45.86 to 68.07 . The supportive educative nursing program is a structured educational program with the assistance of care agents to encourage the community, especially those with heart failure, to improve their quality of life by increasing self-care independence. Self-care management intervention consists of 3 components: self-care maintenance, self-care management, and self-care confidence, which are implemented simultaneously and developed from the situation-specific theory of Self-care Heart Failure (Riegel, Dickson and Faulkner, 2016). Self-care heart failure focuses on improving the self-efficacy of heart failure patients in carrying out daily self-care activities, including self-monitoring of body weight and fluid retention, adherence to prescription drugs and regimens, and maintaining a low sodium diet, exercise, and routine control over doctor.

Several studies have shown that good selfcare will provide a good quality of life for heart failure patients. Self-care for patients with heart failure has a crucial role in affecting the quality of life of patients. Changes in self-care will be in line with changes in quality of life. Factors that influence self-care are not only 
physiological factors (decreased functional capacity) but also other factors such as knowledge, psychological conditions (anxiety), social support, the patient's role in the family, and socioeconomic conditions (Laksmi, Suprapta and Surinten, 2020).

Table 4. Paired T-Test Result in the Control Group (CI 95\%)

\begin{tabular}{lllll}
\hline & Mean \pm SD & $\Delta$ Mean \pm SD & t & p-value \\
\hline Pre-Test & $46.29 \pm 6.888$ & $-1.714 \pm 1.637$ & -3.917 & 0.002 \\
\cline { 1 - 2 } Post-Test & $48.00 \pm 6.816$ & & & \\
\hline
\end{tabular}

Table 4 shows that in the control group given education by the standard operating procedure for discharged planning in hospitals, there was also a significant difference between pre-test and post-test self-care with a $\mathrm{p}$-value $=0.002$, where $\mathrm{p}<\alpha$ (0.05). It is consistent with the research results from Khoiriyati (2011) that the provision of education is effective in improving self-care and quality of life for heart failure patients. Education is an interactive process to add new knowledge, attitudes, and skills through strengthening certain practices and experiences. At the same time, discharge planning is a program of providing health education to patients, including nutrition, activities/exercises, medicines, and special instructions, namely signs and symptoms of the patient's disease (Potter and Perry, 2010). The education provided following the hospital's discharge planning procedure in the control group helps patients understand their condition, recognize worsening signs and symptoms, medications, and control time to return to the hospital.

The analysis results in both groups showed that the education given to both the intervention group and the control group was the same sign to improve self-care for patients with heart failure. Therefore, an Independent T-Test was conducted between the two groups to analyze the supportive educative nursing program's effectiveness in the following table 5 .

Table 5. The results of the Independent T-Test Between the Control Group and the Intervention Group

\begin{tabular}{lllll}
\hline & Mean \pm SD & $\Delta$ Mean \pm SD & t & p \\
\cline { 1 - 2 } Post Test in Control Group & $48.00 \pm 6.816$ & $20.071 \pm 1.974$ & 10.170 & 0.017 \\
\cline { 1 - 2 } Post Test in Intervention Group & $68.07 \pm 2.841$ & & & \\
\hline
\end{tabular}


The analysis results in table 5 show a significant difference between the self-care post-test in the control group and self-care post-test in the intervention group with a $\mathrm{p}$ value (0.017), which means that statistically, the provision of the supportive educative nursing program is more effective than regular education. In the intervention group, respondents were provided with a booklet and self-care videos to develop respondents' abilities in symptom monitoring and treatment adherence, symptom management, and evaluation, implementation of care to the evaluation process, to generate a selfconfident perception that they are capable of self-care, in contrast to the control group, which was only given regular education without a mentoring program. The education was only given once, and the evaluation was carried out eight weeks after that.

According to Orem's conceptual model of Self Care theory, the supportive educative nursing program is a nursing intervention development. One of the nursing interventions in Orem's Self Care theory's conceptual model besides the full compensation system and the partial compensation system is the support system and the education system. This system helps patients who need educational support in the hope that the patient can manage self-care
(Orem, 2001 in Alligood 2014). This system is implemented through a particular supportive educative nursing program for heart failure patients based on self-care heart failure. Self-care heart failure is focused on increasing heart failure patients' selfefficacy in carrying out daily self-care activities, which include self-monitoring of body weight and fluid retention, adherence to prescription drugs and regimens, maintaining a low sodium diet, exercise, and common control (Baptiste et al., 2013).

In the intervention group, the booklet's material describes information related to signs and symptoms of heart failure, selfcare management to the patient's daily schedule, which can influence the dimensions of self-care maintenance and self-care monitoring of respondents. In contrast, educational videos contain much motivation that can change perceptions to improve respondents' self-care confidence. It can be seen from the value of post-test self-care in the intervention group increased in these three dimensions. The intervention group's increase in self-care in this study is consistent with previous studies, where selfcare skills among heart failure patients improved after being given a continuous educational program. One of the study results by Zamanzadeh et al., (2013), there 
was a significant difference in self-care between the control group and the intervention group who were given a continuous education program for three months.

\section{CONCLUSION}

Supportive educative nursing programs are more effective in increasing self-care for heart failure than regular education according to discharge planning procedures. Educational programs given to patients should be accompanied by nurses and equipped with attractive educational media so that the information conveyed is understood and implemented by the patient.

\section{ACKNOWLEDGMENT}

The authors thank any parties supporting this study, especially to Ristekdikti, to provide opportunities and support in this research. The authors also thank STIKES Bina Usada Bali and Mangusada Regional Hospital for the facilities and all their assistance in completing this research.

\section{REFERENCE}

Alligood, M. 2014. Nursing theorists and their works. 8th. St Louis Missouri: Mosby Elsevier.

Baptiste, D. et al. 2013. A nurse-guided patient-centered heart failure education program. Journal of Nursing Education and Practice, 4(3): 49-57.
DOI: 10.5430/jnep.v4n3p49.

Britz, Jody A, and Dunn, K. S. 2010. Selfcare and quality of life among patients with heart failure. Journal American Academic Nurse Practice, 22(9). DOI: 10.1111/j.1745- 7599.2010.00538.x.

Britz, Jody A., and Dunn, K. S. 2010. Selfcare and quality of life among patients with heart failure. Journal of the American Academy of Nurse Practitioners, 22(9): 480-487. DOI: 10.1111/j.1745-7599.2010.00538.x.

Etemadifar, S. et al. 2014. The effectiveness of a supportive educative group intervention on family caregiver burden of patients with heart failure. Iran Journal Nursing Midwifery Res, 19(3): 217-223.

Ibrahim, A. F., Tawfik, F. M., and Abudari, M. O. 2016. Using a self-care management tool to improve self-care and quality of life in patients with congestive heart failure. Clinical Nursing Studies, 4(3): 1-17. DOI: 10.5430/cns.v4n3p1.

Indiarti, E. T. 2014. Latihan Fisik Outpatient Pada Penderita Gagal Jantung Kronik Meningkatkan Kapasitas Fungsional dan Activity Daily Living. Jurnal Kesehatan Stikes Satriya Bhakti Ngajuk, 2(1).

Kaawoan, A. 2012. Hubungan Self Care dan Depresi dengan Kualitas Hidup Pasien Heart Failure di RSUP Dr. R. D. Kandou Manado. Jakarta: Universitas Indonesia.

Kabo, P. 2012. Bagaimana Menggunakan Obat-Obat Kardiovaskular Secara Rasional. Jakarta: Balai Penerbit Fakultas Kedokteran Universitas Indonesia.

Kemenkes. 2013. Riset Kesehatan Dasar. Jakarta: Kemenkes RI 
Khoiriyati, A. 2011. Efek Pendidikan Kesehatan Terhadap Perawatan Diri Pasien Gagal Jantung: Kajian Pustaka. Majalah Keperawatan Unpad, 13(1).

Lakdizaji, S. et al. 2013. Effect of educational program on quality of life of patients with heart failure: a randomized clinical trial. Journal of caring sciences, 2(1): 11-118. DOI: $10.5681 /$ jcs.2013.002.

Laksmi, I. A. A., Suprapta, M. A. and Surinten, N. W. 2020. Hubungan Self Care Dengan Kualitas Hidup Pasien Gagal Jantung Di RSD Mangusada. Care: Jurnal Ilmiah Ilmu Kesehatan, 8(1): 39. doi: 10.33366/jc.v8i1.1326.

Mangusada Regional Hospital. 2018. Heart Failure Patient Medical Record Data. Badung: RSD Mangusada

O'Connor, C. M. et al. 2009. Efficacy and safety of exercise training in patients with chronic heart failure HFACTION randomized controlled trial. JAMA - Journal of the American Medical Association, 301(14): 14391450. DOI: $10.1001 /$ jama.2009.454.

Pereira, J. de M. V., et al. 2016. Nursing Diagnoses of hospitalized patients with heart failure: A longitudinal study. Revista da Escola de Enfermagem, 50(6): 929-936. DOI: 10.1590/S0080-623420160000700008.

PERKI. 2015. Pedoman Tatalaksana Gagal Jantung. Jakarta: Indonesia Heart Asosiation.

Potter, P., and Perry, A. 2010. Fundamental of Nursing: Consep, Proses, and Practice. 7 th edn. Jakarta: EGC.

Riegel, B., Dickson, V. V., and Faulkner, K. M. 2016. The situation-specific theory of heart failure self-care revised and updated. Journal of Cardiovascular
Nursing, 31(3): 226-235. DOI: 10.1097/JCN.0000000000000244.

Sugiyono. 2011. Metode Penelitian Kuantitatif dan Kualitatif dan $R \& D$. Bandung: CV Alfabeta.

Wahyuni, A. and Kurnia, O. S. 2014. Hubungan Self Care dan Motivasi dengan Kualitas Hidup Pasien Gagal Jantung. Jurnal Kesehatan Masyarakat, 2(2): 108-115.

Zamanzadeh, V. et al. 2013. A SupportiveEducational Intervention for Heart Failure Patients in Iran: The Effect on Self-Care Behaviours. Nursing Research and Practice, 1-7. DOI: 10.1155/2013/492729. 